\title{
Çocukluk Çağında İmmunglobulin A Vasküliti: Tek Merkez Deneyimi
}

\author{
Immunoglobulin A Vasculitis in Childhood: One-Center Experience
}

${ }^{1}$ Ankara Şehir Hastanesi, Çocuk

Romatoloji Kliniği , Ankara, Türkiye

${ }^{2}$ Adana Şehir Hastanesi, Çocuk Sağlığı ve Hastalıkları Kliniği, Adana, Türkiye
Correspondence:

Elif CELİKER

Ankara Şehir Hastanesi, Çocuk Romatoloji Kliniği , Ankara, Türkiye e-mail: elifcelikel06@gmail.com
${ }^{1}$ Elif Çeliker, ${ }^{2}$ Ulaş Özdemir

$$
\text { Özet }
$$

Bu çalışmada, immunglobulin A (IgA) vasküliti tanısı ile takip edilen çocukların klinik özelliklerinin, laboratuvar bulgularının, tedavilerinin ve prognozunun değerlendirmesi amaçlanmıştır. 2018-2020 tarihleri arasında merkezimiz Çocuk Romatoloji Kliniği'nde IgA vasküliti tanısı alan, en az 6 ay izlemine devam edilen, 139 cocuğun tıbbi kayıtları geriye dönük olarak değerlendirildi. 139 hastanın 75’i kızdı

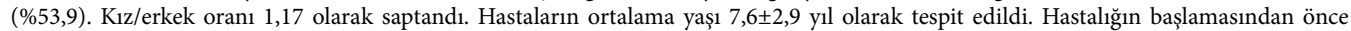
hastaların 118 'inde (\%84) geçirilmiş üst solunum yolu enfeksiyon öyküsü mevcuttu. Klinik bulgulardan döküntü, hastaların tamamında mevcuttu. Hastaların 91'inde (\%65,5) cilt altı ödem, 89’unda (\%64) artralji; 68'inde (\%48,9) artrit, 54'ünde $(\% 38,8)$ karın ağrısı, 30’unda $(\% 21,5)$ renal tutulum, 6'sında (\%4.3) testis tutulumu tespit edildi. Laboratuar bulguları değerlendirildiğinde hastaların 28'inde (\% 20,1) lökositoz ve trombositoz, 29 'unda $(\% 20,8)$ akut faz reaktanlarında yükseklik tespit edildi. İzlemde 30 hastada renal tutulum gelişti. Renal tutulum olan 9 hasta (\%30) tedavisiz izlenirken, 18'ine diğer sistem tutlumları nedeni ile nonsteroid antiinflamatuvar ilaç, 3’üne (\%10) renal tutulum için steroid tedavisi verildi. Dört hasta (1 makroskobik hematüri, 3 nefrotik proteinüri) çocuk nefroloji bölümüne yönlendirildi. Hastaların 30'u (\%21,5) tedavisiz izlenirken 56 hastaya $(\% 40,2)$ non-steroidal antiinflamatuar ilaç, 51 hastaya $(\% 36,6)$ steroid tedavisi verildi. Takipte $17(\% 12,2)$ hastada hastalık tekrarladı. IgA vasküliti cilt ve eklemler başta olmak üzere birçok organ ve sistemi tutabilen bir vaskülittir, hastaların çoğu sekelsiz iyileşmektedir. Bununla beraber erken ve geç dönemde gelişebilecek gastrointestinal ve böbrek tutulumu gibi komplikasyonlar açısından hastaların yakın takip edilmesi gerekmektedir.

Anahtar Kelimeler: IgA vasküliti, çocukluk çağı, MEFV, prognoz

\section{Abstract}

The aim of this study was to evaluate the clinical characteristics, laboratory findings, treatment and prognosis of children with immunoglobulin A (IgA) vasculitis diagnosis. The medical records of 139 children who were diagnosed with IgA vasculitis in our center's Pediatric Rheumatology Clinic between 2018-2020, who continued follow-up for at least 6 months, were retrospectively evaluated. 75 of 139 patients were girls (53.9\%). The male / female ratio was 1.17. The average age of the patients was $7.6 \pm 2.9$ years. Prior to the onset of the disease, 118 (84\%) of patients had a history of upper respiratory tract infection. From clinical findings, the rash was present in all patients. Subcutaneous edema in 91 (65.5\%), arthralgia in $89(64 \%)$; arthritis was detected in $68(48.9 \%)$, abdominal pain in $54(38.8 \%)$, renal involvement in 30 $(21.5 \%)$, testicular involvement in $6(4.3 \%)$ of the patients. In the laboratory evaluation, leukocytosis and thrombocytosis were detected in $28(20.1 \%)$, and increased in acute phase reactants in $29(20.8 \%)$ of the patients. During the follow-up, renal involvement developed in 30 patients. Nine patients $(30 \%)$ with renal involvement were followed without treatment, 18 were given nonsteroidal anti-inflammatory drugs for other system involvement, and steroid treatment was given to $3(10 \%)$ for renal involvement. Four patients (1 macroscopic hematuria 3 nephrotic proteinuria) were referred to the pediatric nephrology department. Thirty $(21.5 \%)$ of the patients were followed without treat ment, 56 patients $(40.2 \%)$ were given non-steroidal anti-inflammatory drugs, and $51(36.6 \%)$ patients were treated with steroids. The disease recurred in 17 (12.2\%) patients during follow-up. IgA vasculitis is a vasculitis that can involve many organs and systems, especially the skin and joints, and most of the patients recover without sequelae. However, patients should be followed up closely in terms of complications such as gastrointestinal and kidney involvement that may develop in the early and late stages.

Keywords: IgA vasculitis, childhood, MEFV, prognosis 


\section{Giriş}

İmmunglobulin A (IgA) (Henoch Schölein purpurası) vasküliti çocukluk çağının en sık görülen sistemik vaskülitidir $(1,2)$. Trombositopenik olmayan ele gelen purpura, artrit/artralji, karın ağrısı, gastrointestinal kanama ve glomerulonefrit tablosu ile karakterizedir. IgA vasküliti, 3-26,7100.000 insidansı ile ağırlıklı olarak bir çocukluk çağ 1 hastalığıdır (1-4). Yapılan çalışmalarda 1,21.8/1 arasında bildirilen erkek-kadın oranları ile erkek üstünlüğünü göstermektedir $(1,5)$.

Hastalığın ortaya çıkmasındaki neden net olarak bilinmemekle birlikte olguların yaklaşık yarısında, özellikle Streptokoklara bağlı gelişen üst solunum yolu enfeksiyonlarının rol oynadığı bildirilmiştir (6). Esas olarak sonbahar, kış ve ilkbaharda ortaya çıkmaktadır (4). Hastalığın oluşumunda immünolojik, genetik ve çevresel faktörler rol oynamaktadır. Hastalık IgA birikiminin karakteristik olduğu, etkilenen organlarda IgA immün komplekslerinin eşlik ettiği lökositoklastik vaskülittir. IgA vaskülitine doğrudan neden olan hiçbir mutasyon gösterilmemiştir. Hastalık neredeyse her zaman sporadik olarak ortaya çıkar. Bununla birlikte yapılan çalışmalar, IgA vaskülitli hastalarda ailesel Akdeniz ateşinin (AAA) gelişiminden sorumlu genin (Mediterrenean Fever (MEFV)) mutasyonlarının sık görüldüğü ve bu mutasyonları olan hastalarda daha yüksek inflamatuar yanıtla birlikte daha şiddetli klinik bulguların olabileceği bildirilmiştir (7-8).

IgA vaskülitli hastaların büyük çoğunluğu kendiliğinden iyileşir. Tedavi öncelikle destekleyicidir ve yeterli hidrasyon, istirahat ve ağrının semptomatik giderilmesini içerir. Gastrointestinal, böbrek ve diğer organ tutulumlarında steroidler ve immunsupresifler kullanılmaktadır

$\mathrm{Bu}$ çalışmada; merkezimizde 2018-2020 y1lları arasında IgA vasküliti tanısı ile izlenen hastaların klinikleri; laboratuvar özellikleri ve prognozları değerlendirilmiştir.

\section{Gereç ve Yöntemler}

Eylül 2018-Ocak 2020 tarihleri arasında merkezimiz Çocuk Romatoloji kliniğine başvuran 18 yaşından önce IgA vasküliti tanısı alan; en az 6 aylık takibi olan, 139 çocuğun tıbbi kayıtları geriye dönük incelendi. IgA vasküliti tanıs1; 2008 Ankara EULAR/PRINTO/PRES kriterlerine dayanılarak konuldu. Bu kriterlere göre ele gelen purpura varlığında; karın ağrısı, artrit/artralji, renal tutulum (hematüri ve/veya proteinüri), biyopside IgA depolanmas1 görülmesi bulgularından en az birinin birlikte olması koşulu ile tanı konuldu (9). Hastaların cinsiyetleri, yaşları, tanı tarihleri, hastalık öncesinde enfeksiyon öyküsü olup olmadığ 1 ve başvuru şikayetleri kaydedildi. Hastalı̆̆ın hem başlangıcında hem de seyri sırasında cilt, eklem, böbrek, gastrointestinal sistem (GİS) ve diğer sistem tutulumlarına ait klinik bulgular incelendi ve kaydedildi. Daha çok alt ekstremitede yoğunlaşan, simetrik ve purpurik döküntüler karakteristik döküntü olarak kabul edildi. Artralji ve/veya artrit olması eklem tutulumu, karın ağrıs1 ve/veya gaitada gizli kan, melena ve hematemez olmas1 gastrointestinal tutulum olarak kabul edildi. Renal tutulum hastalığın seyri sırasında ortaya çıkabilecek bulgulara göre tanımlandı. Mikroskopik hematuri ( $>5$ eritrosit/40'lık büyütmede) ve/veya nefritik proteinüri (4$\left.40 \mathrm{mg} / \mathrm{m}^{2} / \mathrm{saat}\right)$, nefrotik proteinüri ( $>40 \mathrm{mg} / \mathrm{m}^{2} / \mathrm{saat}$, proteinüri) kaydedildi. Hastalığın akut döneminde tam kan sayımı, eritrosit sedimantasyon hızı (ESH), C-reaktif protein (CRP), üre, kreatinin, kompleman $(\mathrm{C} 3, \mathrm{C} 4)$ düzeyleri, antinükleer antikor (ANA), tam idrar tetkiki ve gaitada gizli kan pozitifliği değerlendirildi. Hastalık tekrarı terimi; asemptomatik 3. ayın sonunda tekrarlayan IgA vasküliti için kullanıldı.

$\mathrm{Bu}$ çalışma için etik kurul onayı 17.06.2020 tarihli Adana Şehir Hastanesi Klinik Araştırmalar Etik Kurulundan alınmıştır (E. Kurul-E-59-257).

\section{Istatistik}

Veriler SPSS programı (SPSS version 21.0; SPSS Inc., Chicago, IL,USA) kullanılarak 
değerlendirildi. Sonuçlar, ortalama \pm standart sapma olarak verildi. Kategorik değişkenler $n$ (\%) olarak özetlendi.

\section{Sonuçlar}

Çalısmaya dahil edilen 139 IgA vasküliti tanılı hastanın 75'i kızdı (\%53,9). Kız/erkek oranı 1,17 olarak saptand 1 . Hastaların yaşları 1,8-15,5 yıl arasında olup ortalama yaş $7,6 \pm 2,9$ y1l olarak tespit edildi. Hastalığın başlamasından önce hastaların 118'inde (\%84) geçirilmiş üst solunum yolu enfeksiyon öyküsü mevcuttu. Klinik bulgulardan palpabl purpura/ekimoz şeklinde döküntü, hastaların tamamında mevcuttu. Beş $(\% 3,5)$ hastada büllöz döküntü saptandı. Hastaların 91'inde $(\% 65,5)$ cilt altı ödem, 89'unda (\%64) artralji; 68 'inde $(\% 48,9)$ artrit, 54'ünde $(\% 38,8)$ karın ağris1, 30'unda $(\% 21,5)$ renal tutulum, 6'sında $(\% 4.3)$ testis tutulumu tespit edildi. Laboratuar bulguları değerlendirildiğinde hastaların 28'inde (\% 20,1) lökositoz ve trombositoz, 20'sinde $(\% 14,3) \quad$ ESH yüksekliği, 29'unda $(\% 20,8)$ CRP yüksekliği tespit edildi. Tüm hastaların $\mathrm{C} 3$ ve $\mathrm{C} 4$ düzeyi normal olarak saptandi. Çalışmadaki IgA vasküliti tanılı hastaların demografik, klinik ve laboratuvar özellikleri Tablo 1'de verilmiştir.

İzlemde 30 hastada renal tutulum gelişti. Mikroskobik hematüri 30/30 (\%100), makroskobik hematüri 1/30 (\%3,3), nefritik proteinüri $8 / 30 \quad(\% 26,7)$, nefrotik düzeyde proteinüri 3/30 (\%10) hastada görüldü. Renal tutulum olan 9 hasta (\%30) tedavisiz izlenirken, 18'ine diğer sistem tutlumları nedeni ile NSAIII, 3 'üne $(\% 10)$ renal tutulum için steroid tedavisi verildi. Dört hasta (1 makroskobik hematüri, 3 nefrotik proteinüri) çocuk nefroloji bölümüne yönlendirildi.

Hastaların 30'u (\%21,5) tedavisiz izlenirken 56 hastaya $(\% 40,2) \quad$ non-steroidal antiinflamatuar ilaç (NSAIİ), 51 hastaya $(\% 36,6)$ steroid tedavisi verildi. Takipte 17 $(\% 12,2)$ hastada hastalık tekrarladı. Hastaların tedavileri ve prognozları Tablo 2'de verilmiştir.

Tablo 1. IgA vasküliti tanılı hastaların demografik, klinik ve laboratuvar özellikleri

\begin{tabular}{|c|c|}
\hline & Bulgular $(n=139)$ \\
\hline Cinsiyet; kız, n (\%) & $75(54)$ \\
\hline Tanı yaşı; ortalama \pm SS (yıl) & $7,6 \pm 2,9$ \\
\hline \multicolumn{2}{|l|}{ Sezona göre dağılım; n (\%) } \\
\hline Kış & $79(56,8)$ \\
\hline Sonbahar & $31(22,3)$ \\
\hline İlkbahar & $24(17,2)$ \\
\hline Yaz & $5(3,5)$ \\
\hline \multicolumn{2}{|l|}{ Klinik bulgular } \\
\hline Döküntü, n (\%) & $139(100)$ \\
\hline Artralji, n (\%) & $89(64)$ \\
\hline Artrit, n (\%) & $68(48,9)$ \\
\hline Cilt altı ödem, n (\%) & $91(65,5)$ \\
\hline \multicolumn{2}{|l|}{ Gastrointestinal tutulum } \\
\hline Karın Ağrısı, & $54(38,8)$ \\
\hline Gaitada gizli kan pozitifliği, n (\%) & $16(11,5)$ \\
\hline İntussepsiyon. $\mathrm{n}(\%)$ & $4(2,8)$ \\
\hline \multicolumn{2}{|l|}{ Renal tutulum } \\
\hline \multicolumn{2}{|l|}{ Hematüri } \\
\hline Mikroskobik hematüri, n (\%) & $30(21.5)$ \\
\hline Makroskobik hematüri, n (\%) & $1(0,7)$ \\
\hline \multicolumn{2}{|l|}{ Proteinüri } \\
\hline Nefritik proteinüri, n (\%) & $8(5,7)$ \\
\hline Nefrotik proteinüri, n (\%) & $3(2,1)$ \\
\hline Testis tutulumu, $\mathrm{n}(\%)$ & $6(4,2)$ \\
\hline
\end{tabular}




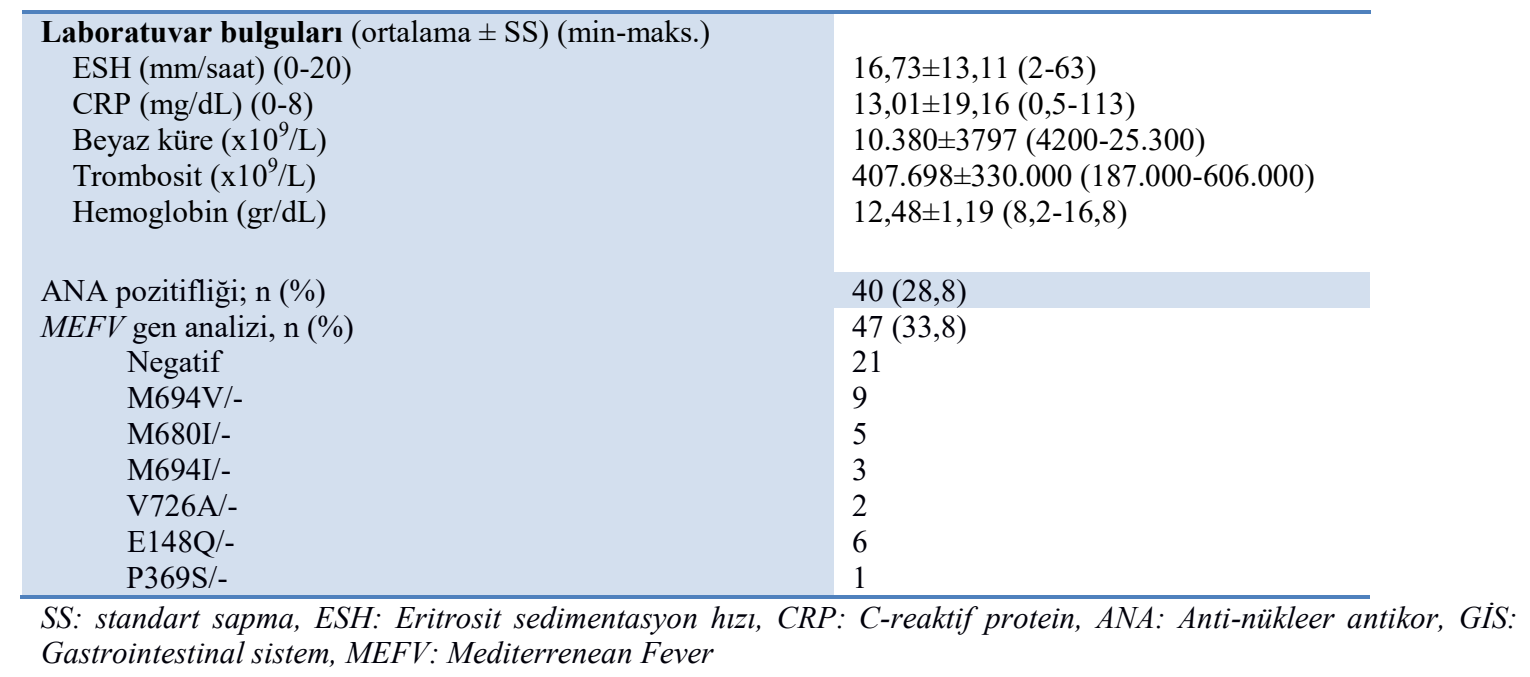

Tablo 2. IgA vasküliti tanılı hastaların tedavi ve prognozu

\begin{tabular}{|c|c|}
\hline \multirow{2}{*}{\multicolumn{2}{|c|}{ Hastalar $(n=139)$}} \\
\hline & \\
\hline Yok & $30(21,5)$ \\
\hline NSAIII & $56(40,2)$ \\
\hline Steroid & $49(35,2)$ \\
\hline Pulse steroid & $4(2,8)$ \\
\hline Steroid endikasyonları & 49 \\
\hline GİS tutulumu & $27(55)$ \\
\hline Yaygın döküntü & $13(26,5)$ \\
\hline Büllöz döküntü & $5(10,2)$ \\
\hline Renal tutulum & $3(6,1)$ \\
\hline Testis tutulumu & $5(10,2)$ \\
\hline \multicolumn{2}{|l|}{ Prognoz } \\
\hline İyileșme & $118(84,8)$ \\
\hline Tekrarlama & $17(12,2)$ \\
\hline Sevk & $4(2,8)$ \\
\hline
\end{tabular}

NSAIII: Non-steroidal antiinflamatuar ilaç, GíS: Gastrointestinal sistem

\section{Tartışma}

İmmunglobulin A vasküliti; etyolojisi tam olarak bilinmeyen, başta cilt olmak üzere eklemler, GİS, böbrekler ile daha az olarak diğer organların etkilendiği, küçük damarları tutan bir lökositoklastik vaskülittir (10). Genellikle 5-15 yaşları arasında, ortalama 5-6 yaş civarında ortaya cıktığı bildirilmektedir (11). IgA vaskülitinin genellikle erkeklerde daha sık görüldüğü bilinmekle birlikte k1zlarda daha yüksek oranda görüldüğünü bildiren bazı çalışmalar da mevcuttur $(12,13)$. Çalışmamızda hastaların ortalama yaşları $7,6 \pm 2,9$ y1l olarak tespit edildi, erkek-k1z cinsiyetleri arasında belirgin fark olmamakla beraber, kızlarda daha sık olduğu görüldü.
IgA vaskülitinin sonbahar ve kış aylarında ve bazı çalışmalarda ilkbahar aylarında daha sık görüldüğü bildirilmektedir $\quad(13,14) . \quad \mathrm{Bu}$ çalışmada da hastaların çoğunluğunun $(\% 56,8)$ kış aylarında başvurduğu saptandı. IgA vaskülitinde yakın zamanda geçirilen enfeksiyonların hastalığ ${ }_{1}$ tetikleyici olabileceği düşünülmektedir. Hastalık sıklığının mevsimsel değişikliğinin üst solunum yolu enfeksiyonlarının sık görüldüğü dönemlerle ilişkili olduğu düşünülmektedir. Çalışmamızda da hastaların \%84'ünde geçirilmiş üst solunum yolu enfeksiyon öyküsü mevcuttu. 
IgA vaskülitinde döküntü, hastaların yaklaşık dörtte üçünde görülen bir bulgudur. S1klıkla eritemli, maküler veya ürtiker döküntüsü ile başlar, ancak hedef lezyonlar dahil daha az tipik sunumlar da görülebilir. Döküntüler kaşıntılı olabilir, ancak nadiren ağrılıdır. İlk döküntüler birleşerek tipik ekimozlara, peteşilere ve palpe edilebilen purpuraya dönüşebilir. Tipik olarak, ekstremitelerde simetrik olarak dağılmış ve esas olarak alt ekstremiteler gibi yerçekimine/basınca maruz kalan alanlarda bulunur. Çoğunlukla kalça ve alt ekstremite gibi vücudun ağırlık taşıyan bölgelerinde yoğunlaşır. Çalışmamızda da tüm olgularımızın döküntüsü mevcuttu. Bazı olgularda büllöz lezyonlar da gelişebilir. Yapılan çalışmalarda çocukluk yaş grubunda IgA vasküliti vakalarında tahmini büllöz döküntü prevalansının $<\% 2$ olduğu öne sürülmüştür (15-18). Bu çalışmada da tüm hastalarda cilt tutulumu olmakla birlikte büllöz döküntü hastalarımızın \%3,5'inde mevcuttu.

Artrit/artralji hastaların \%84'ünde görülür (19). Artrit genellikle geçicidir, tipik olarak oligoartikülerdir ve deformite birakmadan düzelir. Sıklıkla alt ekstremitenin büyük eklemleri (kalçalar, dizler ve ayak bilekleri) tutulur $(19,20)$. Belirgin periartiküler şişlik, hassasiyet varken efüzyon, kızarıklı genellikle eşlik etmez. Hastalarda ciddi ağrı ve hareket kisıtlılığı olabilir. Genellikle bir veya iki günden fazla olmamakla birlikte purpuranın ortaya çıkmasından önce ortaya çıkabilir. Bizim çalışmamızda eklem tutulumunun $\% 48,9$ oranında görüldüğü tespit edildi. $\mathrm{Bu}$ hastalara bulguları düzelinceye kadar NSAIII tedavisi verildi, deformite bırakmadan iyileştiği saptandı.

Gastrointestinal semptomlar, IgA vaskülitli çocukların yaklaşık yarısında görülür. GİS tutulumu genellikle iyi seyir gösterirken ağır tutulum erken dönemde mortalite ve morbiditenin en önemli sebebidir. Klinik olarak karın ağrısı, bulantı, kusma ile kendini göstermekle birlikte daha az sıklıkta melena, hematokezya eşlik edebilir. Dışkıda gizli kan pozitifliği, hastaların \%56'sında bulunur, ancak masif gastrointestinal kanama nadirdir (21). Çalışmamızda olguların \%38,8'inde karın ağrısı, \%11,5'inde ise dışkıda gizli kan pozitifliği ise tespit edildi. İntususepsiyon, IgA vaskülitinin en s1k görülen gastrointestinal komplikasyonudur. Bazı retrospektif serilerde intussepsiyonun genel insidans $1 \% 0,4-0,6$ oranında bildirilmesine rağmen, IgA vaskülitinde insidans \%2,3-3,5 arasındadır $(19,21)$. Ekinci ve ark. intussepsiyon sıklığını \%13,5 olarak bildirmiştir (22). Çalışmamızda ise bu oran $\% 2,8$ olarak saptand.

Böbrek tutulumu IgA vasküliti olan çocukların yaklaşı \%20-54'ünde bildirilmiştir $(6,19,21)$. Büyük çocuklar ve yetişkinler arasında daha yaygın görülebilmektedir (23). Çok merkezli Cure Glomerülonefropati (CureGN) çalışmasında; IgA vasküliti nefritli 161 hastanın (112 çocuk, 49 yetişkin) tanı anındaki medyan yaşı çocuklarda 9 ve yetişkinlerde 35 saptand (24). IgAV vaskülit nefritli hastalarda erkek cinsiyet baskındır. Böbrek tutulumunu öngören risk faktörleri tam olarak belirlenmemiştir, ancak çeşitli klinik ve laboratuar özellikler potansiyel risk faktörleri olarak bildirilmiştir. Chan ve ark. yaptığ 1 meta-analizde; başlangıçtaki ileri yaş, gastrointestinal semptomlar, kalıc1 purpura, nüks, yüksek lökosit sayısı, yüksek trombosit sayıs1, yüksek antistreptolizin $\mathrm{O}$ titresi ve düşük C3 böbrek tutulumu ile ilişkilendirilmiştir (25). Böbrek tutulumu tipik olarak sistemik semptomların başlamasından birkaç gün ila bir ay sonra ortaya çıkar (26). En yaygin prezentasyon mikroskobik veya makroskobik glomerüler hematüri ile hafif veya orta derecede proteinüridir $(21,24)$. Hastaların çok azında nefrotik düzeyde proteinüri, yüksek serum kreatinin ve/veya hipertansiyon mevcuttur; bu bulgular daha kötü renal prognoz ile ilişkilidir (26). Tekrarlayan purpura atakları veya makroskopik hematüri olan hastalarda sıklıkla böbrek semptomlarında şiddetlenme ve glomerüler lezyonlarda biyopsi ile doğrulanan kötüleşme görülür. Çalışmamızda böbrek tutulumu en sik mikroskobik hematüri $(\% 21,5)$ takiben nefritik düzeyde proteinüri $(\% 5,7) \quad$ şeklinde görüldü. Dört hasta (3 nefrotik proteinüri, 1 makroskobik hematüri) böbrek biyopsisi yapılmak üzere çocuk nefroloji kliniğine yönlendirildi. 
Ailevi Akdeniz ateşi; en sık görülen monogenik kalıtımlı otoinflamatuar hastalıktır (27). $M E F V$ genindeki fonksiyon kazanım mutasyonu sonucu pyrin proteinin fonksiyonu bozulur ve aşırı inflamatuar yanıt oluşmasına neden olur (28). AAA'da IgA vaskülitinin normal popülasyona göre daha sık görüldüğ̈̈ bilinmektedir (29). Özçakar ve ark (7) IgA vasküliti hastalarının \%34'ünde sağlıklı bireylere göre daha fazla $M E F V$ mutasyonu taşıdığını gösterdi. Ayrıca M694V mutasyonu taşıyan hasta grubunda artrit, periferik ödem ve ürogenital tutulumun daha s1k olduğu bildirildi (7). Çakıcı ve ark (30), 1120 hastayı içeren geniş kohortunda IgA vasküliti tanılı hastalarda $M E F V$ mutasyonu siklığını \%21,2 olarak bildirdi. $\mathrm{Bu}$ çalışmada, özellikle 10 . ekzon mutasyonu taşıyan hastalarda daha ağır hastalığın geliştiği özellikle vurgulandı (30). Gershoni-Baruch ve ark (31) 52 hastaya içeren çalışmasında hastaların \%27'sinde en az bir $M E F V$ mutasyonu olduğunu, ancak mutasyonu olan ve olmayan hastalar arasinda klinik, laboratuvar ve demografik özelliklerde herhangi bir farklılık olmadığını bildirmiştir (31). Çalışmamızda GIS tutulumu ve yaygın büllöz cilt lezyonları olan 47 hastanın $M E F V$ gen analizi değerlendirildi, 19'u 10. ekzonda olmak üzere 26 hastada $(\% 18,7)$ heterozigot mutasyon saptand1.

IgA vaskülitli hastaların büyük çoğunluğu kendiliğinden iyileşir. Tedavi öncelikle destekleyicidir ve yeterli hidrasyon, istirahat ve ağrının semptomatik giderilmesini içerir. Ağrı tedavisinde en sık kullanılan ilaçlar

\section{KAYNAKLAR}

1. J.M. Gardner-Medwin, P. Dolezalova, C. Cummins, et al.: Incidence of Henoch-Schonlein purpura, Kawasaki disease, and rare vasculitides in children of different ethnic origins. Lancet. 2002;360:1197-1202. PMID: 12401245

2. M. Mossberg, M. Segelmark, R. Kahn, et al.: Epidemiology of primary systemic vasculitis in children: a population-based study from southern Sweden. Scand J Rheumatol. 2018; 47:295-302.

3. Maryam Piram , Alfred Mahr. Epidemiology of immunoglobulin A vasculitis (Henoch-Schönlein): current state of knowledge. Curr Opin Rheumatol 2013;25:171-8.

4. M. Piram, C. Maldini, S. Biscardi, et al. Incidence of IgA vasculitis in children estimated by four-source
NSAIII'dir. Çalışmamızda hastaların \%18,8'i tedavisiz iyileșirken \%40,2'si NSAIII ile ayaktan tedavi edildi. GİS, böbrek ve diğer organ tutulumlarinda steroidler ve immunsupresifler kullanılmaktadır. Ancak bu ilaçların prognoza etkisi ve kullanım endikasyonu açısından dünyada bir görüş birliği yoktur. Böbrek tutulumu tutulumu morbidite ve mortaliteyi belirlemede en önemli prognostik faktördür. Ne yazık ki, erken steroid tedavisi IgA vaskülitli çocuklarda böbrek tutulumunun sıklığını ve şiddetini azaltmamaktadır. 3 aydan uzun süredir proteinüri ile şiddetli nefrit veya böbrek tutulumu olan IgA vaskülitli çocuklarda, sekonder glomerüler hasarı önlemek ve/veya sınırlandırmak için kortikosteroidlere ek olarak bir anjiyotensin dönüştürücü enzim inhibitörü veya anjiyotensin reseptör blokerinin kullanılması düşünülmelidir (32). Çalışmamızda olgularımızın yaklaşık \%40'ına GIS, renal ve yaygın büllöz cilt tutulumu nedeni ile steroid tedavisi verildi. Ek immunsupresif gereksinimi olmadi.

Sonuç olarak; çalışmamızda IgA vaskülitinin cilt ve eklemler başta olmak üzere birçok organ ve sistemi tutabilen bir vaskülit olduğu, k1sa dönemde prognozunun iyi olduğu ve hastaların çoğunluğunun sekelsiz iyileşebildiği görülmüştür. Bununla beraber erken ve geç dönemde gelişebilecek özellikle GİS ve böbrek tutulumu gibi komplikasyonlar açısından hastaların yakın takip edilmesi gerekmektedir. capture-recapture analysis: a population-based study. Rheumatology. 2017; 56:1358-66.

5. Yang $\mathrm{YH}$, Hung $\mathrm{CF}$, Hsu $\mathrm{CR}$, et al. A nationwide survey on epidemiological characteristics of childhood Henoch-Schönlein purpura in Taiwan. Rheumatology (Oxford) 2005; 44:618.

6. Saulsbury FT. Epidemiology of Henoch-Schönlein purpura. Cleve Clin J Med 2002; 69 Suppl 2:SII87.

7. Z.B. Ozcakar, F. Yalcinkaya, N. Cakar, et al. MEFV mutations modify the clinical presentation of HenochSchonlein purpura. J Rheumatol. 2008; 35:2427-9.

8. R. Gershoni-Baruch, Y. Broza, R. Brik: Prevalence and significance of mutations in the familial Mediterranean fever gene in Henoch-Schonlein purpura. $J$ Pediatr. 2003;143:658-61. 
9. S. Ozen, A. Pistorio, S.M. Iusan, et

al. EULAR/PRINTO/PRES criteria for Henoch-Schonlein purpura, childhood polyarteritis nodosa, childhood Wegener granulomatosis and childhood Takayasu arteritis: Ankara 2008. Part II: final classification criteria. Ann Rheum Dis. 2010; 69:798-806.

10. Yang $\mathrm{YH}, \mathrm{Yu} \mathrm{HH}$, Chiang BL. The diagnosis and classification of Henoch-Schonlein purpura: an updated review. Autoimmun Rev 2014;13:355-8.

11. Petty RE. Laxer RM, Lindsley CB, et al. Immuncomplex Small Vessel Vasculitis: IgA vasculitis (Henoch-Schlein). In: Petty RE. Laxer RM, Lindsley CB, Wedderburn LR, Mellins ED, Fuhlbrigge RC, editors. Textbook of Pediatric Rheumatology. 8th ed. W.B. Saunders Co. Philadelphia 2020; 456-66.

12. Shim JO, Han K, Park S, et al. Ten-year Nationwide Population-based Survey on the Characteristics of Children with Henoch-Schönlein Purpura in Korea. $J$ Korean Med Sci 2018; 33:e174.

13. Hwang HH, Lim IS, Choi BS, Yi DY. Analysis of seasonal tendencies in pediatric Henoch-Schönlein purpura and comparison with outbreak of infectious diseases. Medicine (Baltimore) 2018; 97:e12217.

14. Karadă̆ ŞG, Tanatar A, Sönmez HE, Çakmak F, Kıyak A, Yavuz S, Çakan M, Ayaz NA. The clinical spectrum of Henoch-Schönlein purpura in children: a singlecenter study. Clin Rheumatol. 2019;38:1707-1714.

15. Peeters V, De Raeve L. Blistering eruptions in HenochSchönlein syndrome: more common than assumed. Eur J Pediatr 2018; 177:475.

16. den Boer SL, Pasmans SG, Wulffraat NM, et al. Bullous lesions in Henoch-Schönlein purpura as indication to start systemic prednisone. Acta Paediatr 2010;99: 781-3.

17. Kausar S, Yalamanchili A. Management of haemorrhagic bullous lesions in Henoch-Schönlein purpura: is there any consensus? $J$ Dermatolog Treat 2009;20:88-90

18. Ramelli V, Lava S, Simonetti G. Blistering eruptions in childhood Henoch-Schönlein syndrome: systematic review of the literature. Eur J Pediatr 2017;176:487-92.

19. Trapani S, Micheli A, Grisolia F, et al. Henoch Schonlein purpura in childhood: epidemiological and clinical analysis of 150 cases over a 5-year period and review of literature. Semin Arthritis Rheum 2005; 35:143.

20. Calviño MC, Llorca J, García-Porrúa C, et al. HenochSchönlein purpura in children from northwestern Spain: a 20-year epidemiologic and clinical study. Medicine (Baltimore) 2001; 80:279.

21. Chang WL, Yang YH, Lin YT, Chiang BL. Gastrointestinal manifestations in Henoch-Schönlein purpura: a review of 261 patients. Acta Paediatr 2004; 93:1427.

22. Ekinci RMK, Balci S, Sarı GS, et al. Do practical laboratory indices predict the outcomes of children with Henoch-Schönlein purpura? Postgrad Med. 2019; 131:295-8.

23. Ghrahani R, Ledika MA, Sapartini G, et al. Age of onset as a risk factor of renal involvement in HenochSchönlein purpura. Asia Pac Allergy 2014; 4:42.

24. Selewski DT, Ambruzs JM, Appel GB, et al. Clinical Characteristics and Treatment Patterns of Children and Adults With IgA Nephropathy or IgA Vasculitis: Findings From the CureGN Study. Kidney Int Rep 2018; 3:1373.
25. Chan H, Tang YL, Lv XH, et al. Risk Factors Associated with Renal Involvement in Childhood Henoch-Schönlein Purpura: A Meta-Analysis. PLoS One 2016; 11:e 0167346.

26. Narchi H. Risk of long term renal impairment and duration of follow up recommended for HenochSchonlein purpura with normal or minimal urinary findings: a systematic review. Arch Dis Child 2005; 90:916.

27. Ben-Chetrit E, Touitou I. FamilialMediterranean fever in the world. Arthritis Rheum. 2009; 61:1447-53.

28. Lachmann HJ, Sengul B, Yavuzsen TU et al. Clinical and subclinical inflammation in patients with familial Mediterranean fever and in heterozygous carriers of MEFV mutations. Rheumatology (Oxford). 2006; 45:746-50.

29. Can E, Kılınç YZ, Hamilçıkan S, et al. MEFV gene mutations and clinical course in pediatric patients with Henoch-Schönlein purpura. Arch Argent Pediatr. 2018;116: e385-e391.

30. Cakici EK, Kurt Şükür ED, Özlü SG, et al. MEFV gene mutations in children with Henoch-Schönlein purpura and their correlations-do mutations matter? Clin Rheumatol. 2019;38:1947-52.

31. Gershoni-Baruch R, Broza Y, Brik R. Prevalence and significance of mutations in familial Mediterranean fever gene in Henoch- Schonlein purpura. $J$ Pediatr. 2003;143:658-61.

32. Alexander K. C Leung, Benjamin Barankin Kin Fon Leong. Henoch-Schönlein Purpura in Children: An Updated Review. Curr Pediatr Rev . 2020;16:265-76. 